\title{
Economic Turbulence in the Iron Kitchenware Industry in Italy
}

\author{
Maria Garbelli (Senior Lecturer) \\ University of Milano-Bicocca, Italy
}

Doi:10.19044/esj.2018.v14n31p58～URL:http://dx.doi.org/10.19044/esj.2018.v14n31p58

\begin{abstract}
Companies in turbulent economies are required to face several difficulties, mainly related to the specific features of an extremely volatile environment. Although a similar, hypercompetitive context can be considered a global condition today, it is not perceived in the same way worldwide. Thus, international development could be the best method for exporting to different locations and getting the best opportunities to survive in this unstable environment. Italy is one of the European Union countries affected the most by turbulence and the financial crisis with a loss of competitiveness compared to other countries in the Union. The economic system has changed considerably, rising the bankruptcy cases and lowering reported earnings. This paper claims to give an overview of the Italian situation inside the European Community as Italy is recognized as one of the most industrialized areas of northern Italy; the province of Brescia is home of one of the two Italian districts devoted to the iron kitchenware industry - an industry in which Italy held a leading position worldwide for a long time. Ten years after the financial crisis, and supported by exports flows analysis, we evaluate the Italian competitive position in this industry compared to that of the country's European competitors. Export data (inside and outside the European Union) in three years $(2007,2010$, and 2014) show Italy's leading global role in this industry but also the negative effect of the crisis on the country, witnessed by the strong rise of other competitors.
\end{abstract}

Keywords: Turbulence, exports, Italy, performance, competitive position

\section{Introduction}

In this paper, turbulence is recognized to be the main feature of global markets, generally qualified by hypercompetition (D'Aveni, 1994), oversupply (Brondoni, 2005), the rise of competitive networks (Garbelli, 2014) and most of all, unsteady economic conditions. In 2007, the turbulence was reinforced by the American financial collapse, and the following global 
economic/financial crisis. During the crisis, markets became more unsteady, turbulent, unpredictable and complex than before.

The aim of this work is to go beyond the wide number of indexes and data to express the overall effect of the crisis on a specific country, to provide insights into the dynamics of a specific, representative industry. Following the idea that in times of crisis companies expand abroad to find new markets for their products, it could be possible to identify a criterion for estimating the impact of turbulence: the loss of market share. For this reason, this work does not tackle of financial crisis as public authorities and scientific literature have examined the topic in several ways, considering the impact of the crisis on a business, on society or on the country as a whole; we claim few studies have investigated the impact generated on the international development effects of a selected industry.

To provide evidence of the topic, we identify the 2007 as the year generating turbulence worldwide; the analysis examines Italy as one of the countries affected by the financial crisis. Using data from Cribis (an Italian research institute and available online at www.cribis.it) and considering 2009 the year the crisis's negative effects started, bankruptcies increased in Italy by around 63\%. In 2015, the number decreased for the first time since 2009 ($5 \%)$.

Table 1: Bankruptcies in Italy according to Cribis

\begin{tabular}{|c|c|c|c|c|c|c|c|}
\hline Year/number & $\mathbf{2 0 0 9}$ & $\mathbf{2 0 1 0}$ & $\mathbf{2 0 1 1}$ & $\mathbf{2 0 1 2}$ & $\mathbf{2 0 1 3}$ & $\mathbf{2 0 1 4}$ & $\mathbf{2 0 1 5}$ \\
\hline failures & 9384 & 10888 & 11840 & 12124 & 14010 & 15336 & 14585 \\
\hline
\end{tabular}

Table 2: Failure growth rate per year in Italy

\begin{tabular}{|c|c|c|c|c|c|c|}
\hline variation per year & $\mathbf{2 0 1 0 / 2 0 0 9}$ & $\mathbf{2 0 1 1 / 2 0 1 0}$ & $\mathbf{2 0 1 2 / 2 0 1 1}$ & $\mathbf{2 0 1 3 / 2 0 1 1 2}$ & $\mathbf{2 0 1 4 / 2 0 1 3}$ & $\mathbf{2 0 1 5 / 2 0 1 4}$ \\
\hline failure rate & $16 \%$ & $9 \%$ & $2 \%$ & $16 \%$ & $9 \%$ & $-5 \%$ \\
\hline
\end{tabular}

International trade data are available on the Cribis main private and public online database, but to evaluate the competitive position of a specific country in international trade compared to other countries, further analysis is required. The paper focuses on a quantitative analysis of exports before, during and following the financial crisis. Evaluating the changes in market share and the main country destinations, the aim of this paper is to provide evidence of the effects of the 2007 crisis on international commerce.

\section{Literature review}

In recent years, due to the big change in the general environment conditions, the literature has focused on the different effects produced for companies. With a clear understanding of the relevance of such a change, several contributions have been published to support businesses and practitioners in global but turbulent times, linking theory to empirical studies on several topics. For Mella and Gazzola (2016), the main challenge for 
companies all over the world in recent years is managing the unpredictable and fast changes in the turbulent environment, while Lambin (2007) and Brondoni (2005) suggest a market-driven approach to get closer to the market and serve it faster and better.

Defined by Mintzberg and Gosling (2002) as the pattern of all external conditions and influences affecting a company's life and development, the environment has been classified over time in several well-known ways: internal and external or national, regional or local, according to the criteria we intend to apply. If we consider the changeability of the environment, it is possible to distinguish the following (North and Varvakis, 2016): a stable environment, a rapidly changing environment and a turbulent environment. A stable environment offers stability and predictability for companies (providing enough time to organize the available resources, and thus, the business's lifecycle, as external disruptive changes are few and easy to predict and market demand can not be completely satisfied as it is beyond the offers production abilities (Brondoni, 2008). In contrast, a turbulent environment has frequently been associated with an economic recession - negative economic growth for two or more consecutive quarters (Okpara and Wynn, 2007), a crisis or an economic downturn (Sobri et al., 2016). Using Mintzberg's definition, the particular pattern of a turbulent environment - complex, fluid and highly dynamic (AdeniyiAjondabi et al., 2015), difficult to predict (Emery and Trist, 1965) and lacking control (Stigter, 2002) — is qualified by changes that are several, continuous, substantial (disruptive), uncertain and unpredictable. Steihm and Townsend (2002) identified the acronym VUCA (Volatility, Uncertainty, Complexity, Ambiguity) to describe turbulence referring to the modern world of work. Following these features, Ansoff and Mcdonnell (1990) defined a multilevel model to distinguish five levels of turbulence (Table 3), applied by several authors in the following years (Kipley and Lewis, 2009; Kurtz and Varvakis, 2016).

Table 3: Levels of turbulence

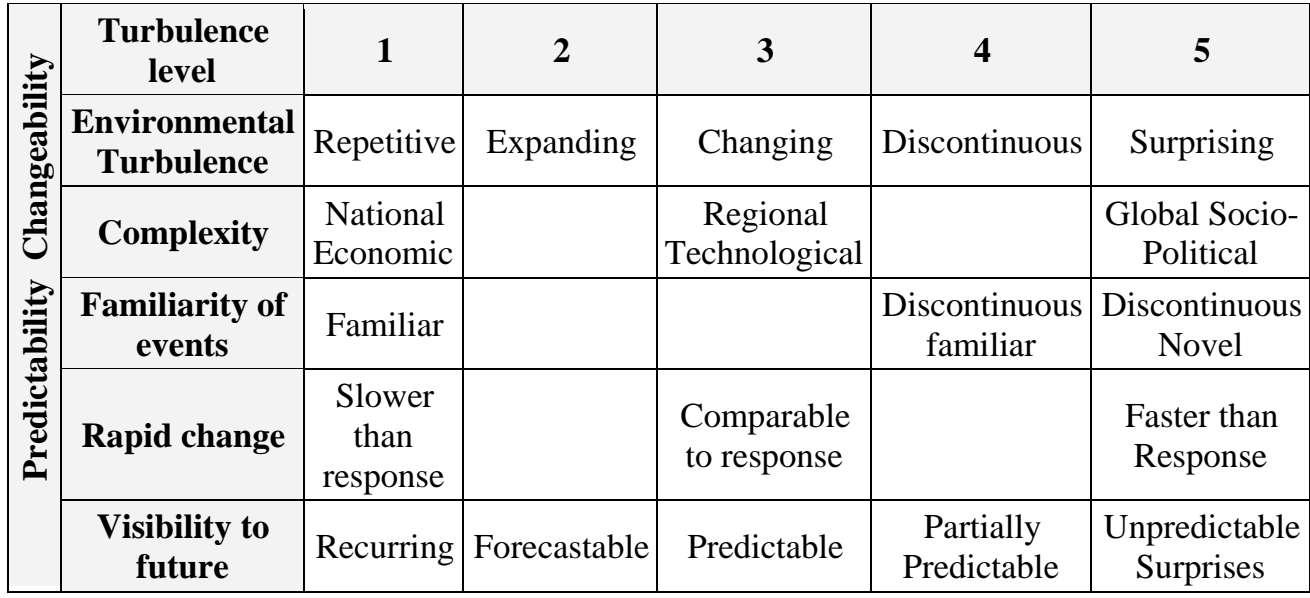


As external conditions become difficult, companies change in structure and behavior; entrepreneurial attitudes (the motivation toward an economic activity) also change considerably during turbulent times. Sobri et al. (2016) demonstrated that an unsteady environment frustrates people, and entrepreneurs tend to be less creative and innovative if they are not supported by a strong attitude. Farkas (2016) evaluated the effects of turbulence on entrepreneurial orientation (using three dimensions: innovativeness, proactiveness and risk taking) and on learning orientation (commitment to learning, shared vision and open-mindedness).

Due to discouraging features, a turbulent environment is difficult for big corporations and small ones (Stigter, 2002). Big corporations, which are stronger and have easily invested financial resources, are more likely to enter strategic alliances and develop a competitive network on their own. Small corporations are dynamic and can react more flexibly but face major challenges due to limited resources (human, financial and organizational). Both types of corporations must be agile, to be able to do different things in different ways quickly in response to change, implying an ability to learn (Horney and Pasmore et al., 2010).

\section{Methodology}

Based on the upon considerations, the understanding of the financial crisis negative effects, can be outlined by examining a specific country industry and estimating changes occurred in competitive positions in the global market. If strong shrinkages in secondary (or less relevant) markets is expected, due to the unsteady and turbulent environment generated by the crisis along with weak competitive advantages and market positions, it is less predictable to assess whether the same effects could also be extended to primary industries.

The market share loss evaluation needs a selected industry as simple. One of the Italian's which has witnessed the power of Italian producers all over the world for several decades is the iron kitchenware industry. This industry fits the research goal, due to the industry's relevance worldwide. After the Second World War, several companies (mostly small and medium size) changed from producing combat equipment and military weapons to producing completely different products with the same raw materials: pots and cutlery. Today, in Italy about 3,900 workers are employed in the industry, with $€ 865$ million of production every year, according to the FIAC Association.

According to Unioncamere 2016 data (www.unioncamere.it), northern Italy is the most industrialized area of the country, counting for around $45 \%$ of all Italian businesses. The iron kitchenware industry is mainly located in two geographic areas in the northern region, which developed as industrial districts of brands known worldwide: the Verbano-Cusio-Ossola (the home of the Sambonet and Lagostina brands) and the industrial area surrounding 
Lumezzane (Brescia). Brescia is the home of several big corporations (e.g., Bialetti, Risolì, Mepra and Inoxriv) and a network of small and medium enterprises, which supply bigger companies (mainly in Italy and Germany) and without any final market relationships.

The industry witnessed a strong threat during the 1970s due to Asian competition (mainly from China). More recently, the 2007 financial crisis eroded Italy's competitiveness compared to its European neighbors.

Market share is evaluated with an export analysis. Following the suggestion of a local entrepreneur, to describe the whole country exports we identified three Tares codes for international commerce: 73239300 (described as "Table, kitchen or other household articles and parts thereof, of iron or steel; iron or steel wool; pot scourers and scouring or polishing pads, gloves and the like, of stainless steel"), 82151020 ("Sets consisting of one or more knives of heading 8211 and at least an equal number of spoons, forks or other articles of heading 8215, of base metal, containing only articles plated with precious metal") and 82152010 ("Sets consisting of one or more knives of heading 8211 and at least an equal number of spoons, forks or other articles of heading 8215 , of stainless steel, containing no articles plated with precious metal"). As the code 73239300 is used for the largest number of products, we chose this code for use in the analysis.

We chose data for exports outside the European Union (EU) for three reasons. The first refers to the availability of data: Although it was easy to find data about international trade between Italy and other European countries, it was harder to find the same data for EU competitors. The second refers to the specific features of the industry: Data about intra-EU trade mostly refers to mid-production for Germany and other countries. Therefore, fluctuations in intra-EU exports could refer to fluctuations in EU buyer international trade and thus, are not directly connected to the Italian industry. Last, it has been supposed that the financial and economic turbulence generated by the crisis affected all EU countries almost at the same time, forcing them to find nationalbased solutions.

Therefore, this study is based on a quantitative evaluation of the fluctuations in Italian exports compared to the exports of other European countries. Data for the following three years were compared: 2007 (when the effects of the global crisis hit, and Italy showed the first weak signs of crisis and decline), 2010 (the eye of the country's financial crisis) and 2014 (what is commonly considered "the point of change" to describe the end of the recession in Italy).

After the industry was chosen, the research questions were formulated to develop the analysis of EU exports, national exports and local Brescia exports. The following research questions were formulated:

R1: Has Italy held its competitive position since 2007? 
Rla: Did the European exports outside the EU increase or not, as a reaction to the global crisis and the turbulent environment?

$R 1 b$ : Did the Italian exports change in a similar way or not?

Rlc: Which EU countries increased revenue (and market share) from international trade?

The first question investigated, through the analysis of the exports, whether European international trade was affected or reinforced as a consequence of the crisis. Export data outside the EU were requested from the European Commission' Market Assess Database, available online (http://madb.europa.eu), which lists the exports of European countries all over the world. The analysis compared the export performance of the European Union as a whole, to provide evidence for the best destination (where EU exports are stable or increasing) and for weak or lost destinations (where exports are decreasing or small). The first research question concerns Italy's competitive position in the European arena.

The second question focused on comparing the results with the exports of every country in the European Union, in order to state whether their international trade development was similar and to select the main exporters.

R2: Did the financial crisis impact the Italian international trade geography?

To answer the second research question, we had to identify the main Italian destinations for export, in order to compare the different geographic localization during 2007 and 2014. This research question examines the ability (or not) of the country to face environment turbulence due to the financial crisis. To answer this question, first we investigated the Italian export data, depending on whether the destination was inside or outside the European Union (to underline the export trends in the two areas) and then analyzed the exports on the different continents. Finally, we compared the main destinations in 2007,2010 and 2014.

\section{Results}

To answer our research questions, we needed data about international trade, of the European Union (hereafter EU) as a whole but of the Countries within also.

Two Italian and international public databases, listed as follow, offered all the data needed for our aim:

- The national institute of public statistics for Italy - www.istat.it

- The european data warehouse institute www.europa.eu

The first research question focuses on Italy's market power and changes due to the crisis's turbulence effects. These effects are understood with the three sub-questions. The first sub-question is about the European Union's 
export performance, as Italy is part of an economic network. The total exports in 2014 were $€ 331,993.161$.

Table 4a: Export outside the European Union in value

\begin{tabular}{|c|c|c|c|}
\hline EXPORT & $\mathbf{2 0 0 7}$ & $\mathbf{2 0 1 0}$ & $\mathbf{2 0 1 4}$ \\
\hline Value (euro) & 315.697 .701 & 318.791 .015 & 331.993 .161 \\
\hline
\end{tabular}

Table 4b: Export trend the European Union in percentage

\begin{tabular}{|c|c|c|c|}
\hline EXPORT & $\mathbf{2 0 1 0}$ vs 2007 & $\mathbf{2 0 1 4}$ vs 2010 & 2014 vs 2007 \\
\hline Trend (\%) & $0,98 \%$ & $4,14 \%$ & $5,16 \%$ \\
\hline
\end{tabular}

In order to catch the export change in between two compared years, the following formula was applied:

[export (year+x) - export (year)]/export (year).

External EU exports rose by 5.16\% during 2007-2014. Exports stagnated during the 2007-2010 period (when exports grew less than 1\%) and a larger increase in the 2010-2014 period. The data showed that exports outside the EU increased very slowly during the 2007-2010 period but increased markedly during the following period (2010-2014).

Rla: Did European exports outside the EU increase or not, as a reaction to the global crisis and the turbulent environment?

According to the data, we can conclude that the crisis deeply affected international export trade in the preliminary stages, but thus far, contingent turbulence seems to have been overtaken by the European Union as a whole. The related sub-questions ( $\mathrm{R} 1 \mathrm{a}$ and $\mathrm{R} 1 \mathrm{~b}$ ) examined the exports of $\mathrm{EU}$ countries, to single out their competitive attitudes and positions. Nations were classified according to the economic value of their exports compared to that of the EU. Based on the weight of the 2014 exports, the countries are clearly divided into two main groups: Within the first are all nations with exports that accounted for less than $1.5 \%$ of the total EU exports. Therefore, Bulgaria, Croatia, Cyprus and Estonia (with low exports, less than $€ 50,000$, compared with other European countries) are not discussed. The second group contains all nations that accounted for more than $2 \%$ of the total EU exports. There are two subgroups. In the first subgroup, six countries have exports worth less than $€ 16$ million. Three (Belgium, the Netherlands and Austria) account for almost $5 \%$ or more of the total EU exports, while the others (Portugal, Spain and Sweden) each account for less than 3.3\%. For this reason, in order to take into account all the relevant changes in international trade during that period, the analysis included the three most important countries and in some cases, included all the countries. In the second group are the three top exporters. Each country had more than $€ 52$ million in exports and together accounted for more than $66 \%$ of the total extra EU export trade. 
The two subgroups are clearly differentiated in the economic consistency of the exports, with a deep gap between the three top exporters and the other six. Not one country has exports between the $€ 16$ million and $€ 52$ million levels.

Table 5: Countries with significant exports flows

\begin{tabular}{|r|r|c|r|}
\hline \multicolumn{2}{|c|}{$\begin{array}{c}\text { Countries with flows } \\
\text { between 16mil and 8mil€ }\end{array}$} & \multicolumn{2}{c|}{$\begin{array}{c}\text { Countries with flows } \\
\text { higher than } \mathbf{5 2} \text { mil } €\end{array}$} \\
\hline Countries & \% on EU & Countries & \% on EU \\
\hline Belgium & $5,09 \%$ & Germany & $29,70 \%$ \\
\hline Netherland & $4,87 \%$ & Italy & $20,67 \%$ \\
\hline Austria & $4,54 \%$ & France & $15,90 \%$ \\
\hline Portugal & $3,29 \%$ & \multicolumn{2}{|}{} \\
\hline Spain & $2,47 \%$ & \multicolumn{2}{|c}{} \\
\hline Sweden & $2,45 \%$ & \multicolumn{2}{|c}{} \\
\hline
\end{tabular}

Defining the intra-EU competitive environment, we singled out the export trends for the six (three plus three) countries, to underline particular changes or potential threats.

Table 6: Exports analysis: The top EU exporters

\begin{tabular}{|c|c|c|c|c|c|c|c|}
\hline Top 5 exporters & $\mathbf{E U}$ & GERMANY & ITALY & FRANCE & BELGIUM & NETHERLAND & AUSTRIA \\
\hline $\begin{array}{r}\text { export value } \\
2014 \text { vs } 2007\end{array}$ & $5,16 \%$ & $22,37 \%$ & $\begin{array}{c}- \\
28,82 \%\end{array}$ & $13,17 \%$ & $53,39 \%$ & $131,67 \%$ & $127,97 \%$ \\
\hline trend vs. EU & & + & - & + & ++ & +++ & +++ \\
\hline $\begin{array}{r}\% \text { export on } \\
\text { EU } 2014\end{array}$ & & $29,70 \%$ & $20,67 \%$ & $15,90 \%$ & $5,09 \%$ & $4,87 \%$ & $4,54 \%$ \\
\hline $\begin{array}{r}\text { Var weight vs } \\
\text { EU }\end{array}$ & & $16,37 \%$ & $\begin{array}{c}- \\
32,31 \%\end{array}$ & $7,62 \%$ & $45,86 \%$ & $120,30 \%$ & $116,78 \%$ \\
\hline
\end{tabular}

R1b: Did the Italian exports change in a similar way or not?

Rlc: Which EU countries increased revenue (and market share) from international trade?

Table 6 shows Italy's market share loss: since 2007, the EU exports increased by $5.16 \%$, Italian competitors as well. These countries gained market share, while Italy outlines shrinkage.

In answer to R1b, Italian exports in value did not change according to the EU's. but comparing Country performance to the Union's, national performance decreased markedly, while EU exports increased substantially.

In answer to R1c, the EU country that gained from this situation is Germany (the new European leader outside the EU). However, France, Belgium, the Netherlands and Austria showed a fast substantial increase in international trade outside the EU.

In order to find clues to give answer to the second research question, we analyzed the Italian exports destination countries in 2007 and in 2014 and therefore we intends to discuss the main differences. Italian exports shrunk 
during the 2007-2014 period. Table 7 shows the results in value (euros) and in percentage. Such a decrease accounted overall for $29 \%$ of the exports. These data help to conceive a more comprehensive answer to the first research question but also as analysis basis for the second one.

Table 7: Comparison of intra-EU and extra-EU Italian exports, in revenue

\begin{tabular}{|c|c|c|c|c|c|c|c|c|c|c|c|c|c|c|c|c|}
\hline \multirow{2}{*}{$\begin{array}{c}\text { EXPO } \\
\text { RT }\end{array}$} & \multicolumn{2}{|c|}{2007} & \multicolumn{2}{|c|}{2008} & \multicolumn{2}{|c|}{2009} & \multicolumn{2}{|c|}{2010} & \multicolumn{2}{|c|}{2011} & \multicolumn{2}{|c|}{2012} & \multicolumn{2}{|c|}{2013} & \multicolumn{2}{|c|}{2014} \\
\hline & $€$ & $\%$ & $€$ & $\%$ & $€$ & $\%$ & $€$ & $\%$ & $€$ & $\%$ & $€$ & $\%$ & $€$ & $\%$ & $\boldsymbol{\epsilon}$ & $\%$ \\
\hline UE 28 & 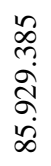 & $\frac{\stackrel{\circ}{~}}{\stackrel{\sigma}{\sigma}}$ & $\begin{array}{l}\underset{\infty}{\infty} \\
\dot{j} \\
\stackrel{\sigma}{+} \\
\dot{\infty}\end{array}$ & $\begin{array}{l}\frac{0}{6} \\
\dot{f}\end{array}$ & 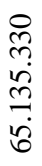 & $\begin{array}{l}\stackrel{\circ}{\Im} \\
\stackrel{f}{f}\end{array}$ & 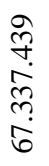 & $\begin{array}{l}\stackrel{0}{0} \\
\text { } \\
\text { in }\end{array}$ & 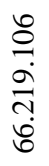 & 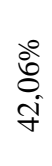 & $\begin{array}{l}\text { ô } \\
0 \\
i \\
\text { in } \\
\text { in }\end{array}$ & $\frac{\stackrel{0}{~}}{\stackrel{q}{q}}$ & 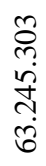 & $\begin{array}{l}80 \\
\dot{0} \\
\dot{b} \\
+\end{array}$ & $\begin{array}{l}\stackrel{0}{0} \\
= \\
\infty \\
\stackrel{\infty}{0} \\
\stackrel{\circ}{n}\end{array}$ & 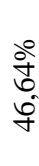 \\
\hline $\begin{array}{c}\text { extra } \\
\text { UE } 28\end{array}$ & 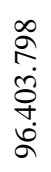 & $\begin{array}{l}\frac{0}{\Delta} \\
\infty \\
\text { in }\end{array}$ & 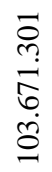 & $\begin{array}{l}\stackrel{2}{2} \\
\text { ñ } \\
\text { n. }\end{array}$ & 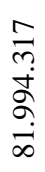 & $\begin{array}{l}\stackrel{0}{2} \\
n \\
n\end{array}$ & $\begin{array}{l}\infty \\
n \\
n \\
\hat{\sigma} \\
\infty \\
i \\
\sigma\end{array}$ & $\begin{array}{l}\frac{0}{5} \\
\hat{a} \\
\text { in }\end{array}$ & $\begin{array}{l}\stackrel{ \pm}{a} \\
\stackrel{n}{\Xi} \\
\frac{n}{a}\end{array}$ & $\begin{array}{l}\text { कo } \\
\text { के } \\
\text { in }\end{array}$ & 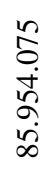 & $\begin{array}{l}\frac{\circ}{\circ} \\
\infty \\
\text { in }\end{array}$ & 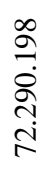 & $\begin{array}{l}\frac{0}{4} \\
m \\
\tilde{n}\end{array}$ & \begin{tabular}{l}
\multirow{J}{*}{} \\
ते \\
ర్ \\
$\infty$ \\
0
\end{tabular} & $\begin{array}{l}\stackrel{0}{0} \\
\text { } \\
\text { n̂. }\end{array}$ \\
\hline $\begin{array}{c}\text { tot } \\
\text { export }\end{array}$ & 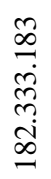 & & $\begin{array}{l}2 \\
\infty \\
0 \\
0 \\
0 \\
0 \\
\infty \\
0\end{array}$ & & 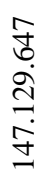 & & $\begin{array}{l}\hat{\sigma} \\
\dot{+} \\
\hat{\jmath} \\
\stackrel{8}{0}\end{array}$ & & 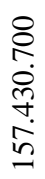 & & 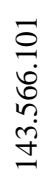 & & $\begin{array}{l}\bar{\sigma} \\
n \\
n \\
n \\
n \\
n \\
n\end{array}$ & & $\begin{array}{l}8 \\
0 \\
0 \\
0 \\
0 \\
\infty \\
\stackrel{0}{0}\end{array}$ & \\
\hline
\end{tabular}

Exports dropped for $29.5 \%$ since 2007. During the first period (20072010), international trade outside the EU collapsed, but intra-EU trade was steady. Trade became unsteady and decreased during the 2010-2014 period.

Table 8: Comparison of intra-EU and extra-EU Italian exports, in percentages

\begin{tabular}{|c|c|c|c|}
\hline EXPORT & $\mathbf{2 0 1 0}$ vs 2007 & $\mathbf{2 0 1 4}$ vs 2010 & $\mathbf{2 0 1 4}$ vs 2007 \\
\hline extra UE 28 & $-3,66 \%$ & $-26,11 \%$ & $-28,82 \%$ \\
\hline UE 28 & $-21,64 \%$ & $-10,92 \%$ & $-30,19 \%$ \\
\hline totale export & $-12,13 \%$ & $-19,73 \%$ & $-29,46 \%$ \\
\hline
\end{tabular}

To understand whether the export destinations changed during that period, we identified the largest export destinations and distinguish Africa, America, Asia, Europe and Oceania. Unfortunately, the official ISTAT database has no data on exports to continents before 2012. Thus, we can discuss the international trade dynamics only during the 2012-2014 period. Exports to the United States were steady during the 2012-2013 period but dropped in the following years (2013-2014). The 2015 data showed an increase in international trade. Exports to Africa increased during the 2012-2014 period, in particular to North Africa and the Middle East. Exports to the BRIC countries in particular decreased during 2015. 
Table 9a: Italian exports in detail. (2015 data counts only the first thee trimesters)

\begin{tabular}{|r|r|r|r|r|r|r|c|}
\hline & AFRICA & $\begin{array}{c}\text { North } \\
\text { Africa }\end{array}$ & $\begin{array}{c}\text { Other } \\
\text { African } \\
\text { countries }\end{array}$ & AMERICA & $\begin{array}{c}\text { North } \\
\text { America }\end{array}$ & $\begin{array}{c}\text { South } \\
\text { America }\end{array}$ & ASIA \\
\hline $\mathbf{2 0 1 5} *$ & 8.163 .144 & 7.162 .722 & 1.000 .422 & 22.960 .698 & 13.006 .789 & 9.953 .909 & 20.853 .851 \\
\hline $\mathbf{2 0 1 4}$ & 5.476 .110 & 4.455 .854 & 1.020 .256 & 19.874 .444 & 10.850 .939 & 9.023 .505 & 20.520 .117 \\
\hline $\mathbf{2 0 1 3}$ & 4.812 .765 & 3.389 .790 & 1.422 .975 & 22.753 .968 & 13.792 .614 & 8.961 .354 & 19.316 .300 \\
\hline $\mathbf{2 0 1 2}$ & 5.219 .992 & 4.608 .181 & 611.811 & 22.779 .201 & 12.574 .859 & 10.204 .342 & 20.767 .567 \\
\hline
\end{tabular}

Table 9b: Italian exports in detail. (continue from table before)

\begin{tabular}{|r|r|r|r|r|r|}
\hline & \multicolumn{1}{|c|}{ Middle East } & Central Asia & \multicolumn{1}{c|}{ East Asia } & \multicolumn{1}{c|}{ BRICS } & \multicolumn{1}{c|}{ OCEANIA } \\
\hline $\mathbf{2 0 1 5}$ & 10.503 .721 & 3.056 .869 & 7.293 .261 & 5.990 .586 & 2.891 .947 \\
\hline $\mathbf{2 0 1 4}$ & 9.962 .991 & 3.162 .014 & 7.395 .112 & 10.369 .054 & 2.812 .635 \\
\hline $\mathbf{2 0 1 3}$ & 8.858 .741 & 2.439 .494 & 8.018 .065 & 11.864 .737 & 2.265 .801 \\
\hline $\mathbf{2 0 1 2}$ & 9.175 .647 & 3.810 .440 & 7.781 .480 & 13.739 .039 & 1.887 .008 \\
\hline
\end{tabular}

The crisis effects can be identified better by identifying the main Italian international trade destinations by country. In this case, the ISTAT database provides details about annual exports since 2007. Using the export data expressed in euros, and compared to the total Italian exports, we found the single country weight. The results are shown in Table 10, showing in detail the power a single country lost during 2007-2014 period.

R2: Did the financial crisis impact the Italian international trade geography?

To answer the second research question, we can confirm strong changes occurred in the destination markets geography.

Table 10: Italian exports: A comparison of 2007 and 2014 destination countries

\begin{tabular}{|r|r|r|r|}
\hline $\begin{array}{c}\text { ITALIAN PARTNERS / } \\
\text { Years }\end{array}$ & $\begin{array}{c}\text { Relevance in } \\
\mathbf{2 0 0 7}\end{array}$ & $\begin{array}{c}\text { Relevance in } \\
\mathbf{2 0 1 4}\end{array}$ & var 2014-2007 \\
\hline Mexico & $1,83 \%$ & $\mathbf{1 1 , 1 5 \%}$ & $333,09 \%$ \\
\hline Israel & $0,46 \%$ & $\mathbf{2 , 3 8 \%}$ & $265,42 \%$ \\
\hline Egypt & $0,69 \%$ & $\mathbf{3 , 3 7 \%}$ & $247,49 \%$ \\
\hline Australia & $2,37 \%$ & $3,93 \%$ & $18,04 \%$ \\
\hline Kazakhstan & $\mathbf{2 , 4 1 \%}$ & $\mathbf{3 , 7 0 \%}$ & $9,38 \%$ \\
\hline United Arab Emirates & $\mathbf{2 , 6 9 \%}$ & $\mathbf{4 , 0 7 \%}$ & $7,52 \%$ \\
\hline Bosnia and Herzegovina & $\mathbf{2 , 2 6 \%}$ & $\mathbf{3 , 4 0 \%}$ & $6,71 \%$ \\
\hline United States & $\mathbf{1 7 , 7 7 \%}$ & $\mathbf{1 4 , 5 1 \%}$ & $\mathbf{- 4 1 , 8 6 \%}$ \\
\hline Russian Federation & $\mathbf{1 6 , 2 7 \%}$ & $\mathbf{1 1 , 8 6 \%}$ & $\mathbf{- 4 8 , 1 2 \%}$ \\
\hline Switzerland & $\mathbf{2 6 , 2 0 \%}$ & $\mathbf{6 , 6 7 \%}$ & $\mathbf{- 8 1 , 8 9 \%}$ \\
\hline Ukraine & $\mathbf{1 , 8 7 \%}$ & $\mathbf{0 , 3 5 \%}$ & $\mathbf{- 8 6 , 6 3 \%}$ \\
\hline
\end{tabular}

Table 10 claims to demonstrate that the countries where Italy retained the biggest market share had the biggest losses: Switzerland, the United States, the Russian Federation and Ukraine. In contrast, the Italian market share in smaller destination countries increased: Mexico was the most important, with 
more than $11 \%$ of Italian exports in 2014 while in 2007 the country received less than $2 \%$.

\section{Conclusion}

Analysis of exports, and specifically, analyzing their change over time, points out Italy's deep economic crisis in the iron kitchenware industry. The contraction phase lasted during the 2007-2014 period and deepened during the last four years (2010-2014).

Italy retained leadership of the European market (in terms of export value) accounting for $30.54 \%$ of the total European exports outside the European Union in 2007. However, within a few years, Italy had lost its power and position. In 2014, the country was in second place, overtaken by Germany (which accounted for $29.7 \%$ of the total European exports outside the EU, while in 2007 accounted for only $25.5 \%$ of EU exports).

Although Europe as a whole has reacted to the turbulence following the crisis, and several countries benefited (such as Germany and France), Italy did not react in the right way. As a result, Italy lost its leadership position and experienced a huge change in the export geography during the study period. Future research could detail the factors that influenced this situation, in order to point out whether this was due to the specific industry or to the country's political orientation. It could be also of interest to highlight the different competitive attitudes of Italy and Germany as their market success in this industry is completely the opposite.

\section{References:}

1. Ansoff I., Mcdonnell E., (1990). Implanting strategic management, Upper saddle river, Perentice-Hall

2. Antonacopulou E.P., Sheafer Z., (2013). Learning in crisis, Rethinking the relationship between organizational learning and crisis management, Journal of Management Inquiry, 23 (1), 5-21

3. Brondoni S.M., (2005), Ouverture de 'Eccesso d'offerta e mercati globali', in Sympnonya. Emerging Issues in Management, www.unimib.it/symphonia

4. D’Aveni H., (1994). Hypercompetition: managing the Dynamics of Strategic Maneuvering, The free press, NY

5. Economics and management in urban economy, issue 127, pp. 2327

6. Emery F., Trist E., (1965). The causal texture of organizational environments, Human Relations, 18(1)12-32

7. Farkas, G., (2016). The effects of strategic orientations and perceived environment on firm performance. Journal of Competitiveness, 8(1) 
8. Garbelli M.E., (2005). Product Differentiation Cost and Global Competition, in Symphonya, Emerging Issues in Management (www.unimib.it/symphonya), n. 1

9. Garbelli, M.E., (2014). Localizzazione produttiva e dinamiche competitive, Giappichelli

10. Hall, R.D. and Rowland, C.A., (2016). Leadership development for managers in turbulent times. Journal of Management Development, 35(8), pp.942-955

11. Horney, N., Pasmore, B., \& O'Shea, T. (2010). Leadership agility: A business imperative for a VUCA world. Human Resource Planning, 33(4), 34

12. Kipley, D. and Lewis, A., (2009). The scalability of H. igor ansoff's strategic management principles for small and medium sized firms. Journal of Global Business Issues, 3(1), p.77

13. Kurtz DJ., Varvakis T., Dynamic capabilities and Organizational Resilience in Turbulent Environments, in North K., Varvakis G., (2016). Competitive Strategies for Small and Medium Entreprises, Springer

14. Lambin, J.J., Chumpitaz R., Schuiling I., (2007). Market-driven management: Strategic and operational marketing. Palgrave Macmillan

15. Mella P., Gazzola P., (2016). As the turbulent environment in periods of accelerated dynamics modifies structures and functions of viable firms", proceedings 2nd International Scientific and Practical Internet Conference "Business Administration in Terms of Turbulent Economy”, Комунальне господарство міст, (127), pp.23-27.

16. Mintzberg H., Gosling J., (2002). Educating Managers Beyond Borders Academy of Management Learning and Education $(1,1)$ - looks beyond conventional business education workers

17. North K., Varvakis G., (2016). Competitive Strategies for Small and Medium Entreprises, Springer

18. Okpara J.O., Wynn P., (2007). Human resource management practices in a transition economy: Challenges and prospects, Management Research News, 31(1), pp.57-76.

19. Sobri, M. M., \& Lucky, E. O. I. (2016). Entrepreneurial Attitudes During Economic Turbulence: Evidence from Nigeria. International Business Management, 10(12), 2391-2397.

20. Stiehm, J. H., Townsend, N., (2002), The U.S. Army War College: Military Education in a Democracy. Temple University Press, p. 6.

21. Stigter, H., (2002). Co-operation as a response to a turbulent environment. EIM Business and Policy Research, 1-40 
22. Teece, D., (2014). The Foundations of Enterprise Performance: Dynamic and Ordinary Capabilities in (Economic) Theory of Firms, Academy of Management Perspectives, 28(4), pp. 328-352. 